\title{
Is Mr. Pickwick a Gentleman or a Comic Character?
}

\author{
Mahmut Terci, PhD
}

Beder University, Tirane

\section{Doi:10.5901/jesr.2015.v5n1s1p131}

\section{Abstract}

\begin{abstract}
The Pickwick Papers has been chosen for analysis for several reasons. First, it is the success of this novel that made Charles Dickens one of the best known writers in the Victorian age. Secondly and more importantly, The Pickwick Papers is Dickens's first novel that has become the seed of his later novels. Thirdly, Dickens had the chance to show his great ability of humor in this novel. In terms of gentility, this novel on the one hand includes the comic gentlemen- such as Mr. Pickwick and his club members- and on the other hand it also includes the typical devious gentlemen such as Jingle, Dodson and Fogg who are extremely selfish and never get ashamed to deceive the others. Our main concern is to analyze the concept of the gentleman in Dickens's works in terms of their positive and negative qualities. At the beginning of the novel we see that Mr. Pickwick is a snob who is the president of a club - which used to be a common habit among rich people in the Victorian time - and enjoys going to parties as well as going to the theatre and watching some sport activities. His innocence and naivety creates some comic misunderstandings and funny adventures. Later, he becomes a benevolent, kind and true gentleman with his comical qualities. His nature attracts the respect of the people around him and although he does not own a family himself his servant eagerly convinces him to live with them like their father. His sincere and gentlemanly behavior makes him a very popular and respectable person in the town they live.
\end{abstract}

Keywords: Charles Dickens, Mr. Pickwick, Victorian gentleman, devious gentleman, true gentleman, comic gentleman

\section{Introduction}

The Pickwick Papers (1836-1837), was the first successful step in Dickens's writing career. Surprisingly, this novel made Charles Dickens one of the best known writers in the Victorian age. This fact can easily be seen in the comments of a few contemporary writers and critics such as J. W. Crocker (1837), R. G. White (1870), and M. Oliphant (1892). What they share in their comments ${ }^{1}$ is the fact that they all appreciate Dickens's brilliant writing skill as well as the characters' popularity in the daily life he had created in The Pickwick Papers.

H. N. Maclean argues that Dickens's first novel has become the seed of his later novels. In his article, entitled 'Mr. Pickwick and the Seven Deadly Sins', he claimed that the pattern Dickens had used in this novel has become his style. At the beginning of the essay Maclean mentions Dickens's admission "first in Great Expectations, then in Drood, that it is from man's personality, not society, that good and evil spring" (Maclean, 198) and then he mentions Edmund Wilson's concern that "it is only with Chuzzlewit that he finds Dickens beginning to "pillory" abstractions: "Selfishness in Chuzzlewit, Pride in Dombey."(Wilson in Maclean, 198) Personally, he believes that "at least six of the seven deadly sins are "pilloried" in Pickwick Papers, which can be regarded as an almost medieval allegory of the dangers besetting man in a world of terror and misery." (198) Then, Maclean suggests that Dickens also followed this pattern in his later novels:

The book's effect upon the reader suggests a four-square bastion of everything Dickens loves and respects, surrounded by a circle of more or less active enemies, of whom, though some are routed, many continue to threaten. In Pickwick this plan concentrates on the individual's struggle against institutional society; but the later novels, increasingly concerned with the struggle of good and evil within man's self, are prepared for here, as the central group resists tempters and destructive influences with much the same weapons employed by man in medieval allegory or Renaissance morality. In succeeding novels, the forces of evil tend to close in and drag down the protagonists. Conclusions to many of these later novels are more and more transparently contrived to appease Dickens's public. However, though the menacing circle is largely thwarted in Pickwick Papers, it is in that novel that the pattern is set for Dickens's later work. (Maclean, 198-199)

As Dickens was not only just a novelist but also a social commentator who criticized the economic, social and

\footnotetext{
${ }^{1}$ See Harold Bloom, Bloom's Classical Critical Views: Charles Dickens, Bloom's Literary Criticism, Infobase Publishing 2008. pp.141143 
moral abuses in the Victorian era, according to me he did not just aim at earning his living through writing, but instead he aimed at raising the social and personal awareness to the personal and social illnesses or disorders. For some readers, Dickens became the teacher of their minds and hearts so that they could understand themselves much better, for some he became a social reformist and developed a strong social consciousness in the society, and for some he was considered as an outstanding artist or playwright who portrayed the English society in such an artistic way that the readers were fascinated or enchanted by the magic of the words he had combined together.

Generally speaking, Victorian writers aimed at making their readers 'laugh', 'cry' by creating 'suspense' using a large variety of characters and themes in their works. It is clear that Dickens preferred making his readers laugh at these comic scenes in this novel to making them cry which he planned to do in his later novels such as Oliver Twist, Nicholas Nickleby, and Hard Times. Although Dickens adds some sentimental scenes when Mr. Pickwick is arrested and sent to the prison at the end of The Pickwick Papers. Nevertheless, the overall story has more comic scenes and it is obvious that his major concern was to entertain his readers. Dickens's first novel has been criticized in terms of its 'formless' and late appearance of Sam Weller, the character who is most responsible for the novels' success. Barry Tharaud combines the perspectives of some critics together who have found various principles of form in The Pickwick Papers as "Alexander Welsh (1967) sees the novel as a satirical work that parodies Scott's Waverley novels; W. H. Auden (1948) sees Pickwick as a mythopoeic character who moves between two poles of mythic experience represented by Dingley Dell and the Fleet prison; John Butt and Kathleen Tillotson (1957) see the Bardell-Pickwick lawsuit and the relationship between Sam Weller and Mr. Pickwick as structural principles that give order to the plot; Edgar Johnson (1952) sees a unique blend of realism and romance that he calls the "realist fairy tale"; and Robert Patten (1967) and Heinz Reinhold (1968) have found a structural principle in the relationship between the main plot and the novel's interpolated stories. Finally, William Axton (1965), following the lead of Monroe Engel (1959) and J. Hillis Miller (1959), investigates how point of view, "governed by Dickens's concept of the attitudes of middleclass society," is the unifying idea and technique in the narrative. All of these viewpoints have contributed to our understanding of the novel, and I have no wish to dispute or enlarge upon them." (Tharaud, 145)

Dickens's transition from sketch writing to sustained narrative could be observed easily in this work. Especially with the appearance of Sam Weller, the work attracted the Victorian readers' attention. While the first issue was sold only 1000 at the beginning, by the end of its run in 1937 nearly 40,000 copies were sold. It was a great a success at that time. More than its literary success Paul Davis mentions how it became a cultural event as follows;

Its success was more than literary. Pickwick was a cultural event that became an industry. ROBERT PATTEN (1978) describes the frenzy: "There were Pickwick hats, canes, cigars, fabrics, coats, song books, china figurines, Weller corduroys and jest books, and Boz cabs. There were imitations, plagiarisms, parodies, sequels, extra illustrations, Pickwick quadrilles, stage piracies, and adaptations." ELIZABETH GASKELL gently satirized this literary mayhem in Cranford (1853) with a newspaper report that describes a man being run over by a train because he is so engrossed in the current installment of the novel. (Davis, 324-325)

The Pickwick Papers was actually first the project of the artist, Robert Seymour and the publisher, William Hall. They planned to produce a series of sporting prints of the Nimrod Club. They just needed some prose narrative commentary for the illustrations and luckily Dickens was chosen for this task. Dickens, who was not familiar with the sporting themes, accepted the offer only if the subject hadn't been limited by the sporting scenes. Seeing this as a great opportunity, Dickens started to show his artistic writing skills doing some modifications on the original plan and choosing another illustrator who illustrated according to his demands. The increased written parts rather than their illustrations gained more importance in the new shape of the work. This episodic novel was influenced by some factors. As Paul Davis thinks that;

Dickens's models for the story were the novels of picaresque tradition, works like ALAN RENÉ LESAGE's Gil Blas and especially such 18th-century English novels as DANIEL DEFOE's Robinson Crusoe, HENRY FIELDING's Tom Jones and Joseph Andrews, and TOBIAS SMOLLETT's Roderick Random and Peregrine Pickle, works he had pored over as a child. These episodic picaresque novels were filled with practical jokes, slapstick situations, and physical comedy, scenes that provided prototypes for many of the comic episodes in Pickwick. MIGUEL DE CERVANTES's Don Quixote and OLIVER GOLDSMITH's The Vicar of Wakefield were also key influences, contributing to the idealism and the sentiment in Dickens's novel. Dickens was especially indebted to Goldsmith's novel for the prison scenes in Pickwick. (Davis, 324)

Due to the fact that Dickens first had to shape the characters and the plot of the novel according to the demands of his publisher, it took some time to put everything according to his own wish and plan. The more Dickens came closer his own style, the more the novel gained its popularity. The incoherence of the interpolated tales in the first part of the story 
could have been the result of the monthly deadlines. Dickens had to write a certain amount of words and hand the parts of the work to the publisher in time. Samuel Weller's entrance in the later chapters into the story increased the number of the readers. So that Dickens shifted the focus from The Pickwick Club to "the idealistic Victorian Quixote and his cockney Sancho Panza... With the introduction of Sam Weller, Pickwick found its centre... The story of their relationship becomes the story of the novel..." (Davis, 327) Thus, Dickens became one of the great comic writers of his time. Having given the general outline of the novel, we start to focus on the characters and their attitudes in terms of their gentlemanly qualities.

While Dickens entertains his readers with the comic adventures of Mr. Pickwick and his club members, the readers also notice which qualities make some characters true gentlemen, and which of them make them wicked gentlemen. On the one hand, we notice that especially Mr. Pickwick transforms himself from being a snob into becoming a true gentleman, on the other hand we see selfish and dishonest Jingle, Dodson and Fogg. These devious and wicked gentlemen also play important roles in Mr. Pickwick's transition to a true gentleman. The mischievous traits we see in Jingle first attracts the anger and hatred of Mr. Pickwick but in the meantime, this anger and hatred is transformed into his generosity and benevolence. It might be easy to show one's generosity - like the country gentleman Mr. Wardle - by giving a lavish feast for the guests but it is not that much easy to forgive your enemies - especially when you have the power to give them the punishment they deserve - and it is rather difficult to give your enemies a hand when they fall into a miserable situation. This is one of the most important qualities of a true gentleman Dickens which portrays in this novel.

\section{The Amusing Pickwickians}

A close investigation is needed at this point to see the comic sides of Mr. Pickwick as well as his gentlemanly behavior he unveils in various difficult situations. At the very beginning of the novel, Mr. Pickwick and his three club members, Tupman, Snodgrass and Winkle are portrayed owning different distinguished abilities. They do not only think that they are really good at different fields - science, love affair, literature and sports respectively - but they are also proud of being highly distinguished gentlemen. With a belief doing a useful research for the society and supporting the social life with their scientific and valuable contributions, they decide to have a journey in the country together. Paul Davis notes their abilities as follows:

Each of the four corresponding members begins the novel as a "humors" character, a person defined by a single dominating obsession: Winkle is the sportsman, Snodgrass the poet, Tupman the lover, and Pickwick the scientific investigator. They are equally inept at their professions, and the opening sketches suggest that the story will progress by mocking their pretensions. Winkle proves to know nothing about hunting, Snodgrass never writes a poem, Tupman loses Rachael Wardle to Jingle, and Pickwick - even with his spectacles on - is stumped by Bill Stump's stone. (Davis, 326)

Mr. Pickwick is quite an interesting character at the beginning of the novel. He is the president of a club, goes to feasts and parties frequently and enjoys appearing in such social gatherings as well as going to theatres and participating in sports like the other ordinary snobs in the society. However, Mr. Pickwick also resembles Miguel De Cervantes's Don Quixote in terms of his goodness, benevolence and innocence. As a result of his old age he is expected to represent wisdom and experience, but he represents the childish innocence. Things in reality and in his imagination or how he perceives things happening around him are completely different. - Not only the comical adventures but also the harsh situations (for example, his being cheated by Jingle and sent to prison) make him a kind of respectable gentleman that the people who are close to him never imagine a life without him.

What are these comical adventures and difficult situations that Mr. Pickwick has to endure so that he combines his comic nature with the gentlemanly behaviors? At the very beginning of the novel, Mr. Pickwick's speech is interrupted by Mr. Blutton calling him a "humbug". The insult made by an 'honorable gentleman' jolts or emotionally shocks Mr. Pickwick. Mr. Blutton is forced to give an explanation what he really means. When Mr. Blutton says that he has used the term not in 'common sense' but in 'the Pickwickian sense', the problem is resolved. Although 'the Pickwickian sense' does not make any sense, Mr. Blutton's acceptance of his being a member of the 'Pickwick Club' makes Mr. Pickwick tolerate his insult at that moment.

The second problem - which seems to be more serious - occurs during their journey. Mr. Pickwick's note-taking while driving and chatting is misunderstood by the cabman, because he thinks that Mr. Pickwick is an informer who has noted down everything he has said. As a result of his fear - that things he has uttered might be used against him - he starts a fight. Luckily, he is rescued by a stranger called 'Jingle', before the dispute ends in a hospital or at a police station. Mr. Pickwick feels indebted to Mr. Jingle and invites him for a drink and a chat with his friends. He cannot see Jingle's selfishness and deceiving character easily at the beginning of the novel. First the verbal attack of Mr. Blutton and then the cabman's physical attack drag Mr. Pickwick to give a harsh response to these people. Dickens prepares the 
Victorian readers to expect dueling as the form of showing courage as well as cleansing honor with blood. His patience and tolerance play important roles - to make him a true gentleman - not to exaggerate these problems. Marshal Gregory believes that ethical issues are seldom recognized although they exist in every human interaction. In his article, Gregory points out that:

\begin{abstract}
Whether we are being treated fairly, sympathetically, compassionately, generously, kindly, honestly, respectfully, and so on are not discretionary issues for us, nor are they ever trivial... We seldom ask whether we continue to breathe but of course our breathing is continuous. So is our involvement with ethical issues. (Gregory, 283)
\end{abstract}

The moral qualities that make a man a true gentleman are often ignored or people prefer sticking or adhering to their prejudices. Mr. Pickwick's reactions - being patient and tolerable - are such qualities that should be considered in the development of his gentlemanly character and personality. Dickens's comical tones in these disputes make it hard to see these ethical issues in the context but as Marshal Gregory states "Dickens's ethical vision taps into rock-bottom human orientations. His vision is simple but goes deep." (Gregory, 300) In the same article, Gregory also pinpoints that

\begin{abstract}
... his grasp of such ethical principles as justice, kindness, honesty, and compassion is both strong and sure. Dickens recognizes that goodness is not always refined, well-spoken, well-dressed, or well-read, and he even knows that goodness isn't immune from being comical and occasionally ridiculous. But he knows goodness vs. oppression and compassion vs. cruelty when he sees them, and he never longs for a transcendent realm of escape. His ethical vision asserts powerfully that the quality of people's lives is created not by the ideologies they applaud in the abstract but by the concrete ethical choices they make in their everyday treatment of each other at business, in the street, at table, and when they need help or are called upon to give help. And he knows how to contrast nourishing and productive ethical choices with those that are demeaning and destructive. (Gregory, 299)
\end{abstract}

What Gregory tries to emphasize is the fact that Dickens's realistic descriptions of the characters and their interactions in the daily life help us to understand the characters' ethical engagements as well as Dickens's ethical vision. Mr. Pickwick is attacked verbally and physically but his reactions to these unkind behaviors are tolerance and patience. The communicative problems are solved easily in a gentlemanly way when these gentlemanly qualities are applied in the human interaction.

The next serious problem occurs when Winkle is enforced for a dueling as a result of the offence to Dr. Slammer. Mr. Jingle is in fact, the responsible person for the offence and dispute because he wears Winkle's new coat for the party.

'Doctor Slammer. He begged me to express his opinion that your conduct of last evening was of a description which no gentleman could endure; and' (he added) 'which no one gentleman would pursue towards another.' (The Pickwick Papers, 35)

Dickens implies that even a verbal attack or an insult might have caused a dueling for a gentleman to recover his honor. Although dueling was considered to be an old-fashioned way of protecting or recovering the honor in the Victorian time, Dickens uses this instrument adding an extra comical issue to the plot. While doing some analysis about the fine gentleman's honor David Castronovo briefly notes about the history of dueling as follows:

Lawrence Stone points out that dueling began to come under heavy fire in the late sixteenth and early seventeenth century because the monarchy was using the rule of law to bring the peers and gentry under the military control of the state. The peers were undergoing a process of being disarmed. The result of this tendency was three centuries of legislation that attempted to bring private acts of violence into disrepute: the state was at war with the gentleman of honor and his code of duel. (Castronovo, 21)

David Castronovo believes that honor and the duel had no legal significance save that connected with legislation on manslaughter and homicide. However, it is difficult to say when and how exactly dueling started but it had begun to lose its popularity in the $17^{\text {th }}$ century. From Dickens's use of the dueling, it can be suggested that his characters, who ask for dueling are the ones whose honors are seriously damaged by the insults. Both of them never take place. Dickens insinuates that dueling never solves any problems. Yet, mutual understanding, dialog and communication are the keys for the gentlemen to solve their problems even if it is the matter of honor.

Not remembering what Winkle has done the day before - because they get heavily drunk - he accepts the dueling. Not only the others' considerations about him that he is a good sportsman but also general beliefs that a gentleman has to prove his courage when a dispute is related to honor is the main reason for his acceptance the challenge. Luckily, the dueling is called off when Mr. Slammer does not recognize Winkle at all. By the way, comically, Winkle explains the reason why he has accepted the challenge as follows: 
'Because, Sir,' replied Mr. Winkle, who had had time to deliberate upon his answer, 'because, Sir, you described an intoxicated and ungentlemanly person as wearing a coat which I have the honour, not only to wear but to have invented--the proposed uniform, Sir, of the Pickwick Club in London. The honour of that uniform I feel bound to maintain, and I therefore, without inquiry, accepted the challenge which you offered me.' (The Pickwick Papers, 42)

It is a matter of honor for Winkle to show his dependence and loyalty wearing the coat just like a uniform. Dickens also implies that wearing a proper item of clothing for the parties (or in their daily life) is one of the criteria for the people's acceptance in the gentry. The appearance used to be important for the people showing their class level. Dickens gives a special care for this issue as it used to be a way for the gentry to show their significant difference. Alfred Jingle's preference to wear Winkle's new suit for the party implies that the clothes people wore used to be an essential factor for the gentry's acceptance. Even today, the clothes that people prefer to wear from its color and material to its brand and fashion have some connections or relationships to their character as well as their social background.

Dickens's approach to the 'gentleman's honor' in this novel is also remarkable because while the 'pride' is a negative moral value for a devious and wicked gentleman, 'honor' is an inseparable value for a true gentleman. At the beginning of the novel, the Pickwikians' feelings about their own qualities are sensed that they feel 'proud' of their distinguished abilities. Dickens slaps the Pickwickians, sometimes kindly and sometimes severely, using comical motifs throughout the novel to make a distinctive difference between 'pride' and 'honor'. Here, David Castronovo's approach to the gentleman's honor has to be mentioned to understand Dickens's perspectives about this issue. Castronovo points out that:

Honor as a social value is no longer obsession with this dishonor, but a positive value: a gentleman of honor is not oversensitive duelist, but the proverbial "truth-telling Englishman," the man of integrity, the man of responsibility and respectability. Honor has gone from being a matter of forms and appearances to being a matter of character.

Dickens also played a major part in prying honor apart from the code of men of birth. His novels are a veritable procession of boys and men who refuse to submit to the world's lies and sordidness and who protect repute and integrity by decent and manly acts of self-assertion. Oliver Twist defends his mother's reputation in the workhouse by giving the bully Noah Claypole a drubbing; Nicholas Nickleby enjoys liberating experience of beating up the brutal school master Squeers, a man who has tried to degrade him by making him a party to the school's corruption; Pip in Great Expectations gains stature as a man when he abandons his snobbery, shows love for a common convict, and learns that gentleness means more than pride of position. (Castronovo, 30)

Similar to Pip, Mr. Pickwick does not only abandon his snobbery but he also integrates his comic character with gentlemanly virtues in this novel. When Mr. Pickwick and his friends are invited to Manor Farm by Mr. Wardle, a country squire, whom they meet at a military review in Chatham, has treated them rather kindly and generously. The Pickwickians have probably thought or felt that they are much superior to the country people. Dickens describes their feelings as follows:

And Mr. Winkle came out with jokes which are very well known in town, but are not all known in the country; and as everybody laughed at them very heartily, and said they were very capital, Mr. Winkle was in a state of great honour and glory. (The Pickwick Papers, 82)

One the one hand, the generosity of this country gentleman as well as his respectful manners makes them so happy that they find great opportunities to show off their talents. On the other hand, kind and humble country people enjoy the jokes of the gentlemen from the town. When the human interactions are observed in two perspectives, which are from Mr. Wardle's and Mr. Pickwick's sides, we see that both parties are happy for various reasons. While the country gentleman, Mr. Wardle, finds an opportunity to show off his kindness and generosity to the gentlemen from the capital, Mr. Pickwick and his friends find a chance to show off their distinctive talents to the people in the country. Winkle's jokes, which are not all known in the country, make everybody laugh heartily. The Pickwickians become the centre of joy. Mr. Pickwick feels great when he reads everybody's glory and happiness in their eyes. Dickens points out this feeling as follows:

The evening glided swiftly away, in these cheerful recreations; and when the substantial though homely supper had been despatched, and the little party formed a social circle round the fire, Mr. Pickwick thought he had never felt so happy in his life, and at no time so much disposed to enjoy, and make the most of the passing moment. (The Pickwick Papers, 82)

During their stay as guests on the farm, the Pickwickians are invited to a couple of entertaining activities for 
gentlemen. Dickens's descriptions of the pastime activities for the gentlemen signify some facts in various dimensions. First, the readers can observe what type of pastime activities gentlemen got involved in in Victorian time. Second, the characters' portraits as well as their interactions are described in a way that readers can get some ideas or conclusions about their thoughts, feelings and manners. Third, the characters' attitudes and their development through the specific incidents give the reader a better chance to observe their gentlemanly qualities. Although Mr. Pickwick is older than his friends, he never thinks to stay behind; instead he prefers participating to the hunting event. Due to his leadership character, he forces himself to participate in the activities and his old age does not prevent him to get involved in them. Moreover, Mr. Pickwick keeps on motivating his friends with his energetic personality and he becomes the centre of enthusiasm. For the Victorian gentlemen the popular recreations used to be going to the theaters, hunting, cricket, dancing or (fancy dress) parties.

The pride of Winkle, Tupman and Mr. Pickwick is beaten or in a way punished by Dickens with the following incidents. Winkle's pride or reputation is damaged when he shoots his friend Tupman accidentally in hunting. However, Tupman becomes happy about this accident because he spends more time with Mr. Wardle's old-aged sister, Rachael, when all the gentlemen go out for the cricket match. Tupman declares his love to her immediately. According to Dickens, love is a serious matter. Tupman's love affair with an old lady becomes a comical instrument in Dicken's descriptions. When Tupman finds out that Rachael has gone away with Jingle his first reaction to this serious problem is described by Dickens as follows:

'I paid his expenses!' said Mr. Tupman, jumping up frantically. 'He's got ten pounds of mine!--stop him!--he's swindled me!-- I won't bear it!---'Il have justice, Pickwick!--I won't stand it!' and with sundry incoherent exclamations of the like nature, the unhappy gentleman spun round and round the apartment, in a transport of frenzy. $(P P, 121)$ (Bold mine)

Which is more important, "ten pounds" or "Rachael"? From Tupman's reactions readers can easily understand that he is not so serious in his love affair. Moreover, when he is found in the pub, readers notice that he has ordered a "big meal" for himself. He is also expected to become very upset and to refuse anything as a result of his sorrow or to harm himself as a result of this eloping. But, Mr. Pickwick finds no difficulty to convince him to continue their journey. Thus, this kind of reaction is not really normal behavior of real lovers in their upset time. According to Dickens, "love" should be considered as one of the most important issues in one's life. David's love to Agnes and Pip's love to Estella are just some examples of real love. Through these characters readers can easily see that the life is meaningless without their lovers' presence and whatever they think or feel is always related to their lovers.

Mr. Pickwick's pride related to his scientific intellect is punished by Dickens with an "ordinary stone" that Mr. Pickwick comes across on the road by chance. Noticing some writing on the stone, Mr. Pickwick suggests that it is an "antique stone" and he feels very proud of himself discovering such a valuable piece. In the meantime, it becomes obvious that the 'precious antique stone' is actually an ordinary stone with a funny message on it. Thus, it is figured out that Mr. Pickwick is also not a professional 'scientist' like the other Pickwickians who believe that they are professionally a sportsman or a lover or a poet. Throughout these funny adventures, readers become aware that the 'sportsman', Winkle, is actually not a great sportsman at all showing his inability in shooting. The 'poet', Snodgrass, cannot come up with his own poem in the social gatherings at all. The 'lover', Tupman's unsuccessful attempt in his first love affair amuses the readers. The 'scientist', Mr. Pickwick, finds himself in an awkward situation when the fact about the stone is proved by one of the club members.

Dickens leads or attracts the attention of the readers to Mr. Pickwick and the awkward situations he cannot get rid of due to his naïve character. Dickens uses Jingle as an evil and witty character to make fun of him and/or to provoke his anger and/or helps him to improve his gentlemanly behavior. From time to time, Mr. Pickwick feels that he has almost lost all his patience. Dickens shows his state of anger as follows:

Nothing in the whole adventure, not even the upset, had disturbed the calm and equable current of Mr. Pickwick's temper. The villainy, however, which could first borrow money of his faithful follower, and then abbreviate his name to 'Tuppy,' was more than he could patiently bear. He drew his breath hard, and coloured up to the very tips of his spectacles, as he said, slowly and emphatically-

'If ever I meet that man again, I'll-' (The Pickwick Papers, 128)

Jingle's offence to one of Mr. Pickwick's friends - calling him Tuppy - really drives him mad. He cannot bear the offence destroying his honor and feelings deeply. In order to relieve and recover his honor and dignity, he really desires Jingle's punishment to get revenge so that he would feel relaxed. However, taking revenge is not a gentleman's honorable quality.

When Mr. Pickwick and Mr. Wardle find the fugitives in London, to their surprise they find out that they have already got married. They cannot give Jingle a punishment but instead, with the help of Sam Weller, who becomes man- 
servant Mr. Pickwick later in the novel, Jingle is convinced to accept $£ 120$ as a bribe -actually Jingle considers it as a compensation-. And then in return, he gives the marriage license back.

'Expensive affair,' said Mr. Jingle. 'Money out of pocket-- posting, nine pounds; licence, three--that's twelve-compensation, a hundred--hundred and twelve--breach of honour--and loss of the lady--' (The Pickwick Papers, 141)

In fact this is not the nastiest thing Jingle has done in the story. He appears again with his worst plan later. Before that we have to follow Dickens how he has portrayed some other funny adventures with his comic characters.

It has been the hospitality and kindness of Mr. (or Esq.) Wardle -the concrete qualities of the country gentleman.Having excellent meals, going to hunting, seeing a cricket match and enjoying the parties have developed their socializing with the country people and have formed wonderful relations and happy memories for the Pickwickians during their stay in Dingley Dell. They have seen sincere hospitality and it has become very difficult for them to leave the kind people behind.

It was a more difficult task to take leave of the inmates of Manor Farm, from whom they had received so much hospitality and kindness. (The Pickwick Papers, 145)

Here, from the descriptions of Dickens we notice that the generosity of the country gentleman or esquire is outstanding. Dickens also portrays the pastime activities for the Victorian gentlemen include long-lasting feasts, hunting, cricket matches and parties.

Mr. Pickwick, who is the centre of the joy and lively atmosphere for the people around him, attracts the readers' appreciation with his comic and lively character. Because Mr. Pickwick cannot see the reality and the facts rapidly, Dickens creates another important character, Sam Weller. He becomes Mr. Pickwick's man-servant. Dickens gives some kind of role to Sam that whenever Mr. Pickwick needs help he is always ready to save his master. Whenever he falls into difficult or awkward situations, Sam is there to give him a hand.

One of the funniest awkward situations that he gets involved is when Mr. Pickwick mixes up his own room in the hotel and enters a room which belongs to a lady.

'Gracious Heaven!' said the middle-aged lady, 'what's that?'

'It's - it's — only a gentleman, ma'am,' said Mr. Pickwick, from behind the curtains.

'A gentleman!' said the lady, with a terrific scream.

'It's all over!' thought Mr. Pickwick.

'A strange man!' shrieked the lady. (The Pickwick Papers, 321-322)

The reason why a special emphasis is given to this funny situation here is that Dickens prefers choosing this term loaded with varied meanings. Secondly, we can observe and analyze much better the gentlemanly qualities in people's attitudes in various circumstances. As in the funny example about Mr. Pickwick, he prefers to communicate with the lady in a very polite way to give her confidence about his real purpose. He stops to search for his own room after this incident not to cause any problem at all. He prefers to wait until the sun breaks the darkness of the night. The polite language he uses, his kindness, and his respect to the lady are the important qualities of a gentleman. This is the very basic usage of the term gentleman which refers to 'a man'. Dickens also prefers to use polite language to address many people with descriptive adjectives as 'jolly old gentleman', 'honorable gentleman', 'respectable gentleman', 'tall gentleman in a blue coat', 'last-named gentleman', 'elderly gentleman', 'young gentleman', 'stout gentleman', 'strange gentleman, 'baldheaded old gentleman', 'fat gentleman', 'enthusiastic gentleman', and so on. The other ways of Dickens's use of the term gentleman is quite noticeable in the following examples.

'Doctor Slammer. He begged me to express his opinion that your conduct of last evening was of a description which no gentleman could endure; and' (he added) 'which no one gentleman would pursue towards another.' (The Pickwick Papers, 35)

Here, the term consists of the qualities such as 'honor', 'dignity', 'grace' and 'glory'. But the following use of the term suggests the 'class distinction' in the Victorian age.

'When I wos first pitched neck and crop into the world, to play at leap-frog with its troubles,' replied Sam. 'I wos a carrier's boy at startin'; then a vaginer's, then a helper, then a boots. Now l'm a gen'l'm'n's servant. I shall be a gen'l'm'n myself one of these days, perhaps, with a pipe in my mouth, and a summer-house in the backgarden. Who knows? I shouldn't be surprised for one.' (The Pickwick Papers, 221)

Readers can easily deduce that the people in the lower class like Sam always had a chance to shift a class as long as they work hard to get a better profession or to get enough money in business. Thus, Dickens uses the term gentleman basically in four ways; the first use refers to 'a man', the second use refers to 'the polite way of addressing 
people', the third use refers to 'conducts or virtues of the people' and the forth use refer to 'the man in upper class'.

Sam Weller is the second important character in the story whose ambition is to become a gentleman as it used to be Dickens's, while he was writing this story. This fact is also another proof that Dickens's first novel is the seed of his later novel as being a respectable gentleman is one of the ambitions of Dickens's character, Sam Weller, as well as Pip's in one of his later masterpieces Great Expectations. Magwitch's obsessive ambition is to turn Pip into a gentleman, which can be done, in his opinion, simply through investing amounts of money in his education. In other words, Magwitch believes that gentlemanship may be bought, which proves entirely false at the end of the novel. While investigating the possible meanings Dickens has loaded in the term gentleman, a close look into the characters' gentlemanly behavior according to the noticeable incidents or situations they have been involved, is needed. As in that funny example about Mr. Pickwick, he prefers to communicate with the lady in a very polite way to give her confidence about his real purpose. He stops to search for his own room due to his fear to get involved in an awkward situation like that. He prefers waiting until the sun breaks the darkness of the night. The polite language that he uses, his kindness, and his respect to the others in order not to disturb them are some of the important qualities of the gentleman which should be mentioned here.

\section{The Devious Gentlemen}

Returning to Pickwick, another awkward situation causes an important crisis between Mr. Pickwick and Mrs. Bardle. She falls into his arms as she misunderstands his real intention. Although Mr. Pickwick wants to imply that a servant is needed, she thinks that he has proposed marriage to her. The appearance of Sam Weller is also attached to the most important plot theme, which is the dispute between Mr. Pickwick and Mrs. Bardle. Although Mr. Pickwick explains that he himself could not conceive why she has fainted and adds that he has just wanted to suggest employing a servant for the home, unfortunately, nobody - even his friends - believes him. The professionally devious gentlemen named Dudson and Fogg convince Mrs. Bardle to sue Mr. Pickwick to get some compensation as a result of his attitudes that caused some damages to her feelings. Dickens weaves new adventures for Mr. Pickwick based on this comic situation in the following chapters. The comic incident is ended in prison.

The parties, where the ladies and gentlemen find a proper chance to meet and to get to know each other better, are used by Dickens to reflect and at the same time to mock the upper class Victorian society. The Pickwickians are invited to a fancy dress party in the morning in Eatenswill. Mr. Pickwick cannot be persuaded to wear a funny costume for the party. Dickens satirizes this kind of events in a different way. First, this fancy dress party, which is held in the morning, is very unusual and awkward because similar parties are usually held in the evening. Second, wearing a funny costume implies for Mr. Pickwick that hiding your real face from others. Having two faces or disguising is an ill-mannered virtue that cannot be tolerated by a gentleman like Mr. Pickwick. Here, Jingle appears again disguised as Mr. FitzMarshall. Mr. Pickwick, who really wants to expose him, becomes the victim of his witty joke again and he finds himself in another awkward situation. Although they were supposed to be careful not to trust them, Mr. Pickwick and Sam believe Job, Jingle's servant and accept his plan. As benevolence becomes Mr. Pickwick's inseparable gentlemanly virtue, he wants to help one of the young ladies in the boarding school. Mr. Pickwick goes there at night does everything according to the plan. But unfortunately, he cannot bare the storm outside and escapes from the natural storm outside to the hysterical women's storm inside the boarding school. Again nobody believes his story and he is rescued by Sam and Mr. Wardle who was there for a hunting expedition. After this incident, Mr. Pickwick's health is affected and he has to spend some time in bed. At that moment, they promise each other to expose Jingle's and Job's real faces. Their witty joke becomes an honor issue for both Mr. Pickwick and Sam. Sam becomes also the other party who has been fooled in this awkward situation. With this experience, he learns that there are still professionally disguised dishonest gentleman and he shares Mr. Pickwick's emotions. The positive point is that they become closer like father and son.

Dickens also portrays how 'anger' or 'jealousy' affects the attitudes of the gentleman using different incidents in the novel. The woman, whose room has been mistakenly occupied for a while by Mr. Pickwick, appears to be the future wife of his friend, Mr. Peter Magnus who has asked some advice from Mr. Pickwick on the way to Ipswich. When they meet again to be introduced by Mr. Magnus, the young lady gets shocked and gives a loud scream. Mr. Magnus asks both parties how they have known each other but none of them would prefer to explain the fact as it is a sensitive case. The more Magnus asks for an explanation from Mr. Pickwick as a result of his jealousy, the more the dispute becomes irresolvable. So he threatens Mr. Pickwick with a duel, which is used for the second time by Dickens in this novel to mock the idea of dueling which used to be a common way to restore their gentlemanly honor. But none of the dueling takes place as Dickens never approves it as a kind of solution when a dispute appears between gentlemen. Meanwhile, the lady takes the case to the local justice stating that a dueling will take place in Ipswich and gives Mr. Pickwick's and 
Tupman's names. Having great difficulty in believing such a dispute will happen in their territory, they decide to investigate the dispute. Mr. Pickwick and Tupman are arrested and at the court they are punished by the judge, Mr. Nupkin. Mr. Pickwick asks for a private talk with him and explains him honestly why they have come to this town. Having learned that a scoundrel, Mr. Fitzmarshal or Jingle, has been flirting with his own daughter, Mr. Nupkin cancels the fine and asks Mr. Pickwick to tell everything to his own family with Jingle's presence. In the end, Mr. Pickwick's honesty is rewarded and Jingle's dishonesty is punished by Dickens. In fact, this is the actual result that usually happens in the social life; as 'honesty is always the best policy' and 'sooner or later the truths appear, and the lies cannot be hidden forever.' Mr. Pickwick's determination to find Jingle and to prevent his evil plans is one of his gentlemanly behaviors that a real gentleman has to be at least as ambitious as the fake gentlemen who destroy the lives of innocent people.

\section{Mr. Pickwick's Troubles with Women}

Mr. Pickwick's examinations with women continue in the novel. This time, he finds out that Mrs. Bardell sues him for the compensation due to the fact that he has destroyed her feelings with the proposal. Mr. Pickwick refuses to pay any money and acts out according to his own principles. It seems that Mr. Pickwick has a stubborn character but in fact, Dickens has a couple of aims in this particular attitude. First, the people like Jingle, Dodson and Fogg really have dishonored him and he (-and also Dickens himself) believes that something has to be done to stop their wrong-doings. Second, accepting to pay even a penny means the admission of his being dishonest and this quality never matches with a real gentleman's character. Third, the more people close their eyes to these greedy people, the richer they become and the more lives they destroy. While some dishonest people like Dodson and Fogg use the laws according to their own benefits in a legal but dishonest way, ordinary people in the society not knowing the details about the laws become the victims of their evil plans. Fourth, Dickens also plans to describe the wretched conditions of the people living in prisons. As he himself stayed in prison because of his father's debt, he knows the life there better than many contemporary writers and he uses it as a chance to satirize the laws related to the debtors' imprisonment. So Dickens shapes his plot as a result of these factors; he wishes to send Mr. Pickwick to prison. More than these factors, Dickens has a plan to show Sam's loyalty to his master and their mutual caring and respect. He also shows us how a real gentleman should behave when he meets his worst enemy in a very wretched situation. Instead of taking revenge, Mr. Pickwick prefers to show his benevolence and generosity even to his worst enemies. This particular gentlemanly attitude of Mr. Pickwick is probably the most important behavior that Dickens portrayed in this novel. The gentility and morality he imposed on this main character is noticeable and highly appreciated by the Victorian readers.

Before Mr. Pickwick is sent to prison, he attends another ball. From Mr. Pickwick's attitude, readers can see that Mr. Pickwick really dislikes the things happening in the aristocratic world. Here, as an individual coming from a lower class, Dickens takes the chance to satirize the foolishness, empty conceit, bootlicking, matchmaking and nastiness of the high society. Mr. Pickwick's gentlemanly character is not portrayed in such balls or in fancy dress parties. We can see Mr. Pickwick's enthusiasm and his jolly atmosphere in other places such as Mr. Wardle's feasts. For instance, Dickens portrays Pickwick's being the centre of fun, joy and respect during his attendance to Mr. Wardle's daughter's marriage ceremony.

It is easily sensed that Mr. Pickwick is in his good mood when he is among his dear friends. He is always generous, energetic, the source of joy and the centre of attention in this kind of gatherings. His juvenile energy and readiness to help his friends when he is needed, has to be noted that the gentlemanly virtues - benevolence and friendship - are also some of the qualities Dickens give a special importance to. In the later chapters, we also observe that although Winkle's own father refuses to support his own son in his marriage, Mr. Pickwick behaves more than a close friend and he takes over the role of the parent. Mr. Pickwick travels a long way to another town not only to talk with Arabella, Winkle's love, to check her confirmation and determination, but also to give a financial aid to Winkle. He talks with Winkle to figure out if they are really serious in their decision like a father. As soon as he becomes sure that they are really serious about the marriage, this time Mr. Pickwick works a lot to convince Winkle's parents in terms of Winkle's need for parental support in this sensitive matter. In time, Winkle's parents realize that they really need to respect their son's choice and to support him.

Dickens also includes a much more touching relationship between Mr. Pickwick and Samuel Weller to show that real gentlemen should possess the qualities such as generosity, friendship and self-sacrifice in their relations. When Mr. Pickwick is sent to the prison, Sam makes himself to be arrested and to be sent to Fleet Prison next to his master. Mr. Pickwick becomes a little bit upset that Sam has made himself to be sent to the prison as a result of his debt. Most probably, Dickens himself has seen and felt these similar scenes in his own life. Because it is not quite is easy to suffer 
hard conditions in the prison, Mr. Pickwick insists on paying the amount for Sam's release but he cannot succeed to persuade him. Because Sam really believes that old Mr. Pickwick needs special care in the harsh conditions of the prison. Sam's loyalty and his self-sacrifice are beyond their friendship. Sam's father who witnesses his son's and Mr. Pickwick's mutual loyalty and kindness, gives Mr. Pickwick a huge amount of money the he has inherited from his death wife. He asks Mr. Pickwick to take care of the money as a result of his trust in the very near end of the story. At first Mr. Pickwick does not want to receive the money but later he takes it just to use and spend it for the sake of Sam and his family to live in better conditions.

During their imprisonment, to their surprise they find out that Jingle and Job also stay in the other poor side of the prison which has worse conditions than theirs. Mr. Pickwick and Sam go to this part of the prison and pay them a visit. They immediately forget their revenge as soon as they see them in that miserable situation.

The general aspect of the room recalled him to himself at once; but he had no sooner cast his eye on the figure of a man who was brooding over the dusty fire, than, letting his hat fall on the floor, he stood perfectly fixed and immovable with astonishment.

Yes; in tattered garments, and without a coat; his common calico shirt, yellow and in rags; his hair hanging over his face; his features changed with suffering, and pinched with famine-- there sat Mr. Alfred Jingle; his head resting on his hands, his eyes fixed upon the fire, and his whole appearance denoting misery and dejection! (The Pickwick Papers, 612)

Instead of just laughing at them or cursing at them or showing any contentment or satisfaction, Mr. Pickwick shares their sorrow. And instead of leaving them in that miserable condition, Mr. Pickwick financially helps them that they can buy some necessary things for their living.

'Good fellow,' said Jingle, pressing his hand, and turning his head away. 'Ungrateful dog--boyish to cry--can't help it--bad fever--weak--ill--hungry. Deserved it all--but suffered much--very.' Wholly unable to keep up appearances any longer, and perhaps rendered worse by the effort he had made, the dejected stroller sat down on the stairs, and, covering his face with his hands, sobbed like a child.

'Come, come,' said Mr. Pickwick, with considerable emotion, 'we will see what can be done, when I know all about the matter. Here, Job; where is that fellow?' (The Pickwick Papers, 614)

Mr. Pickwick's goodness, kindness, generosity and benevolence really touch Jingle's and Job's hearts and they change their way of life after they are released with the help of Mr. Pickwick. They decide to live in another country as it shows their determination to begin a new life with a new start. Although they have been representing devious gentlemen at the beginning of the story, Dickens does some modifications in their characters implying that the opportunities always exist in life for everybody as long as they wish to behave in a better way. With this incident, Dickens portrays the real gentleman through Mr. Pickwick character that forgiveness, benevolence, empathy, good-heartedness and generosity are also their inseparable and indispensable qualities.

Mr. Pickwick also proves that he is a true gentleman forgiving Mrs. Bardell when he sees her in the Fleet Prison. Sam is the key person who brings everybody together - Perker, Arabella and the Pickwickians - and prepares all the conditions which Mr. Pickwick cannot refuse to pay the cost of her lawyers demand. In order to help the ladies - to assist Mrs. Bardell's release and to convince Arabella's brother and Winkle's parents about the marriage - and to make everybody happy with his returning to his social circle again, he accepts the conditions his lawyer, Perker, suggests. The Fleet prison becomes a temporary place for Mr. Pickwick that he has seen the reality of life and his innocence and vindication is approved by his landlady. It has a positive function for Jingle as his evil character changes into a good one. It functions as a kind of slap for Mrs. Bardell that she needs to be awakened from her dream. Although Dodson and Fogg are not punished with imprisonment in the novel, Mr. Pickwick's last words function as a good slap or punishment for them.

'Do you know that I have been the victim of your plots and conspiracies?' continued Mr. Pickwick. 'Do you know that I am the man whom you have been imprisoning and robbing? Do you know that you were the attorneys for the plaintiff, in Bardell and Pickwick?'

'Yes, sir, we do know it,' replied Dodson.

'Of course we know it, Sir,' rejoined Fogg, slapping his pocket --perhaps by accident.

'You are,' continued Mr. Pickwick, resuming the thread of his discourse--'you are a well-matched pair of mean, rascally, pettifogging robbers.'

'Well,' interposed Perker, 'is that all?' 
'It is all summed up in that,' rejoined Mr. Pickwick; 'they are mean, rascally, pettifogging robbers.' (The Pickwick Papers, 768-769) (Bold mine)

These are the worst adjectives which are used in throughout novel by Mr. Pickwick - in fact by Dickens - to describe villainous people. If all the characters in the novel are put in order from good to bad Dodson and Fogg take the worst position as they never get ashamed of what they have done. While the qualities such as selfishness, dishonesty and immorality best describe these wicked gentlemen - albeit their appearance and way of speaking - the qualities such as benevolence, honesty, trustworthy, and reliability best describe the real gentlemen as they can be easily noticed in these characters; especially Dodson \& Fogg verses Mr. Pickwick.

As it has been mentioned before, Mr. Pickwick first helps Winkle in their marriage and then he pays the debts of Jingle to be released from the Fleet Prison. Mr. Pickwick - and of course the readers - has a chance to observe the dark side of life (in prison) and humans during his stay there. At the end of the story, Mr. Pickwick arranges Snodgrass's and Sam's marriages and before that he decides to close down the Pickwick Club saying to the members that;

'I shall never regret,' said Mr. Pickwick in a low voice, 'I shall never regret having devoted the greater part of two years to mixing with different varieties and shades of human character, frivolous as my pursuit of novelty may have appeared to many. Nearly the whole of my previous life having been devoted to business and the pursuit of wealth, numerous scenes of which I had no previous conception have dawned upon me--I hope to the enlargement of my mind, and the improvement of my understanding. If I have done but little good, I trust I have done less harm, and that none of my adventures will be other than a source of amusing and pleasant recollection to me in the decline of life. God bless you all!' (The Pickwick Papers, 814-815)

\section{Conclusion}

In fact, we learn the real aim of Dickens writing this novel which can be mainly summarized as to see the variety of human characters through the amusing and pleasant - or comic - adventures in the life. This is also one of the reasons why we have named, Mr Pickwick as the Comic Gentleman. Mr. Pickwick - and of course Dickens himself - wants to be remembered as the gentleman who has done little good - although a lot due to his modesty - and who has not harmed anybody during his life. Mr. Pickwick devotes his life to happiness of the whole people in the town and is admired a lot by the whole people who know him.

He is known by all the poor people about, who never fail to take their hats off, as he passes, with great respect. The children idolise him, and so indeed does the whole neighbourhood. Every year he repairs to a large family merrymaking at Mr. Wardle's; on this, as on all other occasions, he is invariably attended by the faithful Sam, between whom and his master there exists a steady and reciprocal attachment which nothing but death will terminate. (The Pickwick Papers, 819-820)

Dickens's message at the end is that a true gentleman like Mr. Pickwick should be respected and admired by the people he is in contact with as a result of his honesty, patience, benevolence, and reliability.

\section{References}

\section{Primary Resources}

Dickens, Charles. The Pickwick Papers The Pennsylvania State Univeristy, Electronic Classics Series, USA. 2007

\section{Secondary Resources}

Bloom, Harold. Bloom's Classical Critical Views: Charles Dickens, Bloom's Literary Criticism, Infobase Publishing. 2008,

Castronovo, David. The English Gentleman: Images and Ideals in Literature and Society, The Ungar Publishing Company, New York. 1987

Gregory, Marshall Ethical Engagements over Time: Reading and Rereading David Copperfield and Wuthering Heights, Narrative, Vol.12, No.3 (October 2004), The Ohio State University

Davis, Paul. Critical Companion to Charles Dickens, A Literary Reference to His life and Work, Facts On File, Inc. New York. 2007

Maclean, H. N. Mr. Pickwick and the Seven Deadly Sins, Nineteenth-Century Fiction, Vol.8 No.3 (Dec., 1953) University of California Press

Tharaud, Barry. Form As Process in The Pickwick Papers: The Structure of Ethical Discovery, Dickens Quarterly, Vol.24, No.3 September 2007. 
ISSN 2239-978X

ISSN 2240-0524
Journal of Educational and Social Research MCSER Publishing, Rome-Italy
Vol. 5 No.1 S1 April 2015 